\title{
Biosorption of malachite green from aqueous solutions by Pleurotus ostreatus using Taguchi method
}

\author{
Zhengsuo Chen, Hongbo Deng, Can Chen, Ying Yang and Heng X ${ }^{*}$
}

\begin{abstract}
Dyes released into the environment have been posing a serious threat to natural ecosystems and aquatic life due to presence of heat, light, chemical and other exposures stable. In this study, the Pleurotus ostreatus (a macro-fungus) was used as a new biosorbent to study the biosorption of hazardous malachite green (MG) from aqueous solutions. The effective disposal of $P$. ostreatus is a meaningful work for environmental protection and maximum utilization of agricultural residues.

The operational parameters such as biosorbent dose, $\mathrm{pH}$, and ionic strength were investigated in a series of batch studies at $25^{\circ} \mathrm{C}$. Freundlich isotherm model was described well for the biosorption equilibrium data. The biosorption process followed the pseudo-second-order kinetic model. Taguchi method was used to simplify the experimental number for determining the significance of factors and the optimum levels of experimental factors for MG biosorption. Biosorbent dose and initial MG concentration had significant influences on the percent removal and biosorption capacity. The highest percent removal reached $89.58 \%$ and the largest biosorption capacity reached $32.33 \mathrm{mg} / \mathrm{g}$. The Fourier transform infrared spectroscopy (FTIR) showed that the functional groups such as, carboxyl, hydroxyl, amino and phosphonate groups on the biosorbent surface could be the potential adsorption sites for MG biosorption. P. ostreatus can be considered as an alternative biosorbent for the removal of dyes from aqueous solutions.
\end{abstract}

Keywords: Malachite green, Pleurotus ostreatus, Biosorption, Taguchi method

\section{Background}

Dyes are widely used in textile, leather, paper, rubber, plastics, cosmetics, pharmaceutical, food plants, printing and dyeing industry in China, which consumed large quantity of wastewater from different steps in the dyeing and finishing processes. It is reported that the discharge volumes of these wastewater reaches $14.13 \times 10^{8}$ tons per year [1]. These dyes from such industrial effluents are usually released into the environment which can be carcinogenic, mutagenic, allergenic, toxic to the aquatic life, the food web and can be resistant to natural biological degradation due to presence of these heat, light, chemical and other exposures stable [2], thus upsetting aquatic life [3]. Hence, the removal of such colored agents from aqueous effluents becomes significantly environmental, technical, and commercial importance [4].

\footnotetext{
*Correspondence: xuheng64@sina.com

Key Laboratory of Bio-resources and Eco-environment (Ministry of Education), College of Life Science, Sichuan University, Chengdu, Sichuan 610064, China
}

MG is a cationic dye, an N-methylated diaminotriphenylmethane dye and has been widely used for the dyeing of leather, wool and silk, distilleries, jute, paper, cotton, leather, etc. [5], which is generally used as a strong antifungal, anti-bacterial and anti-parasitical agent in aquaculture [6]. The powerful antimicrobial activity of MG has been attributed to inhibition of intracellular enzymes, intercalation into DNA, and/or interaction with cellular membranes. For its high toxic, high residual, teratogenic, carcinogenic, mutagenic and other side effects to fresh water fish $[7,8]$ and the detection of MG though foodstuff destined to human consumption, alarmed the health hazards against human being. Though the use of this dye has been banned in several countries, it is still being used in many areas due to its low cost, ready availability and efficacy $[9,10]$. In 2002, MG has been prohibited to be used as raw material for all food animals by Ministry of Agriculture of China, but the results of domestic market 
survey showed that: malachite green was still commonly used in aquiculture and aquatic products trafficking.

There are numbers of methods, like decolourisation, coagulation method, chemical oxidation, electrolytic process to eliminate dyes from wastewater. However, studies confirmed that the products formed after degradation of MG were also not safe and had carcinogenic potential $[9,11]$. Adsorption is widely studied and applied for its low cost, high efficiency and easy operation in recent years [12]. The removal of dyes from wastewater is considered to be an important application of adsorption process using suitable adsorbent [13]. Low cost materials such as Prosopis cineraria [14], Hen feathers [15], Jute stick [16], Tea leaves [17], Tricholoma lobayense [1], Bagasse [5] and Peanut husk [18] have been reported to be used as biosorbent for the efficient removal of dyes from aqueous solution.

In this paper, a novel biomaterial $P$. ostreatus was used to remove MG from aqueous solutions. The macro-fungus biomasses (dead, living or their derivatives) had been studied of their adsorptive properties. Previous studies have reported that they have the capacity to bind metals $[19,20]$, dyes [21,22] or other organic pollutant [23]. The macrofungus $P$. ostreatus, commonly known as a mushroom, is an edible basidomycete. No matter in temperate or tropical climates, $P$. ostreatus can be found easily. It is now the second most important cultivated mushrooms in the world [24], and is one of the most common edible mushrooms in China. Its biomass is cheap and easily available. Therefore, the purpose of this study was to evaluate the potential of $P$. ostreatus as a biosorbent to remove MG from aqueous solutions. The operational parameters such as biosorbent dose, $\mathrm{pH}$ and ionic strength were studied. Biosorption isotherm models and kinetics models were studied. Taguchi method was used to determine the significant factors and the optimum levels of experimental factors for MG biosorption. FTIR was used to research the characteristics of biosorbent surface.

\section{Methods}

Adsorbate

MG was used as a representative cationic dye in this study. It was of analytical grade chemicals (C.I. $=42,000$, chemical formula $=\mathrm{C}_{23} \mathrm{H}_{25} \mathrm{ClN}_{2}, \mathrm{FW}=364.92, \lambda_{\max }=617 \mathrm{~nm}$ ) and purchased from Kelong Chemical Reagent Factory, Chengdu, China. The stock solution (1000 mg/l) of MG was prepared by dissolving accurately weighed amount of the dye in distilled water. Experimental solutions of the desired concentrations were obtained by successive diluting the stock solution by distilled water.

\section{Biosorbent}

The macro-fungus $P$. ostreatus was purchased from a mushroom production site near Chengdu, Sichuan. The samples were repeatedly cleaned with deionized water to remove adhering dirt and soluble impurities, and boiled with distilled water three times, each for 3-5 minutes filter with the distilled water until the filtered water was cleared. They were dried at $50^{\circ} \mathrm{C}$ until keep constant weight, then crushed and sieved through 200 mesh $(<75 \mu \mathrm{m})$ sieve to get the smaller particles. The sieved biosorbent were kept in a plastic sealable bag and stored in a desiccator without any further chemical or physical treatment before adsorption experiments.

\section{Characterization of biosorbent}

Fourier transform infrared spectrometer (FTIR) (NEXUS650, America) was used to analyse the functional groups on the biosorbent surface, which may be responsible for MG biosorption.

The $\mathrm{pH}$ at the point of zero charge of the biosorbent $\left(\mathrm{pH}_{\mathrm{PZC}}\right)$, namely the $\mathrm{pH}$ value required to give zero net surface charge, was determined by mass titration. Three solutions with different initial $\mathrm{pH}$ values $(3,6$ and 11 , respectively) were prepared and with the addition of $0.05 \mathrm{M}$ aqueous solution of $\mathrm{HNO}_{3}$ or $\mathrm{NaOH}$, while $\mathrm{NaNO}_{3}$ were used as the background electrolyte. For each initial $\mathrm{pH}$, six Erlenmeyer flasks were filled with $30 \mathrm{~mL}$ of the solution and different amounts of biosorbent were added $(0.05 \%$, $0.1 \%, 0.5 \%, 1 \%, 5 \%$ and $10 \%$ by weight). Then the mixture was shaken for $24 \mathrm{~h}$ at a thermostatic swing shaker. The $\mathrm{pH}$ was measured after the biosorbent was separated. A plot of the equilibrium $\mathrm{pH}$ versus mass fraction yielded a curve showing a plateau and the $\mathrm{pH}_{\mathrm{PZC}}$ was identified as the point at which the change of $\mathrm{pH}$ is zero. The $\mathrm{pH}_{\mathrm{PZC}}$ was then taken as the average of the three asymptotic $\mathrm{pH}$ values [22].

\section{Experimental methods and measurements}

The concentration of MG in the solution before/after equilibrium biosorption was determined by using a double beam UV/vis spectrophotometer to find out the absorbance at $\lambda_{\max }$ of $617 \mathrm{~nm}$. The professional data processing and mapping software Origin 8.5 was used for data analysis and graphics production. Calibration curve for MG was done before all the experiments, by the regression equation, the concentration of MG of every process could calculate precisely. The dye concentrations were measured at time $\mathrm{t}=0$ and at equilibrium, the biosorption capacity at equilibrium, $q_{e}(\mathrm{mg} / \mathrm{g})$, was calculated by using the following equation $[25]$ :

$$
\begin{aligned}
& q_{e}=\left(C_{0}-C_{e}\right) \cdot \frac{v}{w} \\
& \mathrm{P}=\frac{C_{0}-C_{e}}{C_{0}} \cdot 100 \%
\end{aligned}
$$

Where $C_{O}$ is the concentrations of MG at initial time and $C_{e}$ is the concentrations of MG at equilibrium, 
respectively $(\mathrm{mg} / \mathrm{L}) . V$ is the volume of the solution $(\mathrm{L})$ and $W$ is the biosorbent dose $(\mathrm{g}), q_{e}$ is the biosorption capacity per unit mass of biosorbent $(\mathrm{mg} / \mathrm{g})$ and $P$ for the removal efficiency (\%).

\section{Batch biosorption studies}

A series of experiments were carried out in $150 \mathrm{ml}$ stoppered glass Erlenmeyers flasks with $50 \mathrm{ml}$ MG solution to investigate the operational parameters such as the effect of biosorbent dose, initial MG concentration, contact time, $\mathrm{pH}$ and ionic strength. Erlenmeyers flasks were placed at a shaker (SUKUN) with a shaking of $180 \mathrm{rpm}$ and at $25^{\circ} \mathrm{C}$ for $6 \mathrm{~h}$. After biosorption, all the samples were centrifuged with a Centrifuge (Thermo) at 10,000 g for $5 \mathrm{~min}$ to separate the solid phase from the liquid phase, and then analysis of the residual concentration of MG by spectrophotometer. To investigate the effect of biosorbent dose on MG removal, different weight of fungal biosorbent (varying from $0.05 \mathrm{~g}$ to $0.35 \mathrm{~g}$ ) was added in each MG solution (40 mg/L). The effects of the medium $\mathrm{pH}$ on biosorption capacities of the biosorbent was studied from 2 to 10 (i.e. $2,4,6,8$ and 10), which was adjusted by adding a few drops of diluted aqueous solutions of $\mathrm{HCl}$ or $\mathrm{NaOH}(0.10 \mathrm{M})$. Ionic strengths of $\mathrm{MG}$ solutions was studied at four different $\mathrm{NaCl}$ (i.e. 0.05, 0.1, 0.15 and $0.2 \mathrm{M}$ ) and $\mathrm{CaCl}_{2}$ (i.e. 0.05, 0.1, 0.15 and $0.2 \mathrm{M}$ ). All experiments were conducted in duplicates and two controls were performed. Dye control (dye solution without biosorbent) were also shaken using the same procedure. Biosorbent control (biosorbent in double-distilled water without MG) with the same procedure.

\section{Biosorption isotherms and kinetics studies}

Biosorption isotherm models are used to indicate the interactions between adsorbate and biosorbent. The biosorption isotherm models were analyzed using the Langmuir [26] and Freundlich [27] isotherm models to determine the mechanism of biosorption in this study. For the biosorption isotherms studies, biosorption experiments were carried out at different initial MG concentration (i.e. 20, 40, 60, 80 and $120 \mathrm{mg} / \mathrm{L})$.

Three common kinetics models, pseudo-first-order [28], pseudo-second-order [16] and intraparticle diffusion [29] were used to study the mechanism of adsorption. For the kinetic studies, the experimental samples were taken at predetermined time intervals for analyzing the residual dye concentration. Table 1 represents the equation of all the above-mentioned models.

\section{Taguchi method}

The Taguchi method was used to study the effect of various control factors on the biosorption efficient of MG biosorption from aqueous solution and to determine the significant factors and the optimum levels of experimental factors.

The Experiment design of using the Taguchi method is as follows:

1. The percent removal and biosorption capacity were determined as the quality characteristics to be optimized.

2. Selecting the controllable factors that can be set and maintained and determining their alternative levels. In this paper, the design factors include $\mathrm{pH}$, contact time, biosorbent dose, initial MG concentration and three levels of each factor are represented in Table 2.

3. Determining and designing the orthogonal array. $\mathrm{L}_{9}$ $\left(3^{4}\right)$ orthogonal array experiment was selected and designed as shown in Table 2.

4. A series of experiments were conducted from one to another as the designed orthogonal experiment.

5. Statistical Package for the Social Sciences (SPSS) 18.0 statistical software was used for the range analysis and the analysis of variance (ANOVA) of the data and then to determine the most important controllable factors, which can maximize the percent removal and biosorption capacity, then to select the optimal levels for those factors.

\section{Results and discussion}

\section{Discussion}

\section{Characterization of biosorbent}

The FTIR spectra of biosorbent that before-biosorption and after-biosorption to confirm the functional groups are responsible for the biosorption process which were shown in Figure 1.

The biosorbent had much more numbers of biosorption peaks before MG biosorption, indicating that a sufficient number of adsorption sites were existed on the surface of biosorbent. For biological biosorbent materials, it always had broad adsorption peak from 3500 to $3200 \mathrm{~cm}^{-1}$. The intense peaks at 3500 to $3200 \mathrm{~cm}^{-1}$ and $1557 \mathrm{~cm}^{-1}$ representing the stretching vibrations of amino groups [30]. The broad peak, which was observed at the level of 3500 to $3200 \mathrm{~cm}^{-1}$ for both before-biosorption and after-biosorption, indicated the presence of $-\mathrm{OH}$ groups and $-\mathrm{N}-\mathrm{H}$ groups. The peaks at 2924, 2869 and $2852 \mathrm{~cm}^{-1}$ represent the existence of the methyl and methylene groups, and the $2869 \mathrm{~cm}^{-1}$ peak disappeared in the FTIR spectrum of after-biosorption biosorbent, indicating that these groups were responsible for the biosorption process. The peaks at 1736 and $1653 \mathrm{~cm}^{-1}$ represent the characteristics of carbonyl group stretching from aldehydes and ketones in the FTIR spectrum of biosorbent, and the peak shifted to $1652 \mathrm{~cm}^{-1}$ after biosorption [31]. The peak at $1417 \mathrm{~cm}^{-1}$ was the characteristics of bending vibration of $-\mathrm{OH}$. The peak at $1375 \mathrm{~cm}^{-1}$ was for $-\mathrm{CH}_{3}$ 
Table 1 Models equations of biosorption isotherms and kinetics studies

\begin{tabular}{|c|c|c|}
\hline Model & Equation & Symbols representation \\
\hline Langmuir isotherms model & $q_{e}=\frac{k_{a} C_{e} q_{m}}{1+k_{a} C_{e}}$ & $\begin{array}{l}\text { where } q_{e} \text { and } q_{m} \text { are the equilibrium and maximum adsorption capacity of } M G \text {, respectively } \\
\text { (mg/g), } C_{e} \text { is the concentration of } M G \text { at equilibrium }(\mathrm{mg} / \mathrm{L}), k_{a} \text { is the Langmuir constant }(\mathrm{L} / \mathrm{mg}) \text {. }\end{array}$ \\
\hline Freundlich isotherm model & $\ln q_{e}=\ln K_{F}+\frac{1}{n} \ln C_{e}$ & $\begin{array}{l}\text { where } K_{F}(L / g) \text { and } n \text { are Freundlich isotherm constants which related to biosorption capacity } \\
\text { and biosorption intensity, respectively. }\end{array}$ \\
\hline Temkin isotherm model & $q_{e}=B \ln \left(A C_{e}\right)$ & where $A$ is the Temkin isotherm energy constant $(L / g)$ and $B$ is the Temkin isotherm constant. \\
\hline Pseudo-first-order model & $\ln \left(q_{e}-q_{t}\right)=\ln \left(q_{e}\right)-k_{1} t$ & $\begin{array}{l}\text { where } q_{t} \text { are the biosorption capacity at time } \mathrm{t}(\mathrm{mg} / \mathrm{g}) ; k_{l} \text { is the rate constant of first-order } \\
\text { biosorption }\left(\mathrm{min}^{-1}\right) \text {. }\end{array}$ \\
\hline Pseudo-second-order model & $\frac{t}{q_{t}}=\frac{1}{k_{2} q_{e}^{2}}+\frac{1}{q_{e}} t$ & where $k_{2}$ is the second-order biosorption rate constant ( $\mathrm{g} / \mathrm{mg} \mathrm{min}$ ). \\
\hline Intraparticle diffusion model & $q_{t}=K_{i d} t^{1 / 2}+A_{i}$ & where $K_{i d}$ is the intraparticle diffusion rate constant $\left(\mathrm{mg} / \mathrm{g} \mathrm{min}^{1 / 2}\right)$ and $A_{i}$ is the intercept. \\
\hline
\end{tabular}

stretching vibrations. $-\mathrm{C}-\mathrm{N}$ stretching vibration of amino acid was observed at the peaks of 1321, $1252 \mathrm{~cm}^{-1}$. The peak at around $1153 \mathrm{~cm}^{-1}$ was indicative of $-\mathrm{P}=\mathrm{O}$ stretching vibrations [32]. The peaks at 1083, $1042 \mathrm{~cm}^{-1}$ were the characteristics of bending vibration of $-\mathrm{C}-\mathrm{OH}$. The peak at $898 \mathrm{~cm}^{-1}$ proved that the sulfur in the protein or amino acid also existed. The band between 617 and $536 \mathrm{~cm}^{-1}$ for the biosorbent indicated that the existence of $-\mathrm{C}-\mathrm{N}-\mathrm{C}$ scissoring, which can be only found in protein structure. The FTIR spectra of biosorbent indicated that the functional groups such as, carboxyl, hydroxyl, amino and phosphonate groups on the biosorbent surface could be the potential adsorption sites for MG biosorption.

The pHPZC of biosorbent was 6.52, when the $\mathrm{pH}$ was below the pHPZC, the biosorbent surface was charged positively to limit the adsorption of MG. Nevertheless, when the $\mathrm{pH}$ was above the pHPZC of biosorbent, the surface was charged negative ion to improve the adsorption of MG.

\section{Effect of biosorbent dose on MG removal}

Figure 2 shows that the removal percentage increased with increasing in the biosorbent dose. At equilibrium time of $6 \mathrm{~h}$, the percent removal increased from 58.98\% to $99.58 \%$ for increasing biosorbent dose from 0.05 to
$0.3 \mathrm{~g}$. Above $4 \mathrm{~g} / \mathrm{L}$ of biosorbent dose, the percent removal of dye MG did not bring about a significant improvement in biosorption at biosorption equilibriums. For economic considerations, optimum biosorbent dose was found to be $4 \mathrm{~g} / \mathrm{L}$. The increase of MG removal is owing to the increase of the available biosorption surface areas and availability of more possible biosorption sites with increasing biomass. Similar observations were previously reported for removal of methylene blue from aqueous solution by spent tea leaves [17].

\section{Effect of pH on MG removal}

Dyes in textile industry are complex organic compounds. It is well known that the initial $\mathrm{pH}$ of the solution can affect the degree of ionization of the dyes. The surface of the adsorbents is composed of polysaccharides, proteins and lipids with different functional groups (such as amino, carboxyl, thiol and phosphate groups) could bind of the dye molecules. The initial $\mathrm{pH}$ affects the structural stability of MG and its color intensity [33]. In the preliminary experiment, it observed by naked eyes that the dye color reduction gradually when adjustment solution $\mathrm{pH}$ more than 10 and lower than 2. It may be due to the structural of MG changes being effected at higher $\mathrm{pH}$. MG $(\mathrm{pKa}=10.3)$, the cationic dye, gets protonated in the acidic medium and

Table 2 The results of Taguchi method experiment $\left(L_{9}\left(3^{4}\right)\right.$ orthogonal array experiment design)

\begin{tabular}{|c|c|c|c|c|c|c|}
\hline \multirow[t]{2}{*}{ Trail NO. } & \multicolumn{4}{|c|}{ Operating factors and their levels } & \multicolumn{2}{|c|}{ Results } \\
\hline & A & B & C & D & Percent removal (\%) & Biosorption capacity $(\mathrm{mg} / \mathrm{g})$ \\
\hline 1 & 7 & 5 & 0.15 & 80 & 82.63 & 22.035 \\
\hline 2 & 7 & 6 & 0.2 & 100 & 82.34 & 20.586 \\
\hline 3 & 7 & 7 & 0.25 & 120 & 82.87 & 19.889 \\
\hline 4 & 8 & 5 & 0.2 & 120 & 81.55 & 24.465 \\
\hline 5 & 8 & 6 & 0.25 & 80 & 89.58 & 14.333 \\
\hline 6 & 8 & 7 & 0.15 & 100 & 81.51 & 27.171 \\
\hline 7 & 9 & 5 & 0.25 & 100 & 85.57 & 17.134 \\
\hline 8 & 9 & 6 & 0.15 & 120 & 80.82 & 32.329 \\
\hline 9 & 9 & 7 & 0.2 & 80 & 85.95 & 17.191 \\
\hline
\end{tabular}

A: $\mathrm{pH}$; B: contact time (h); C: biosorbent dose (g); D: initial MG concentration $(\mathrm{m} / \mathrm{l})$. The results were the mean of three parallel ones. 


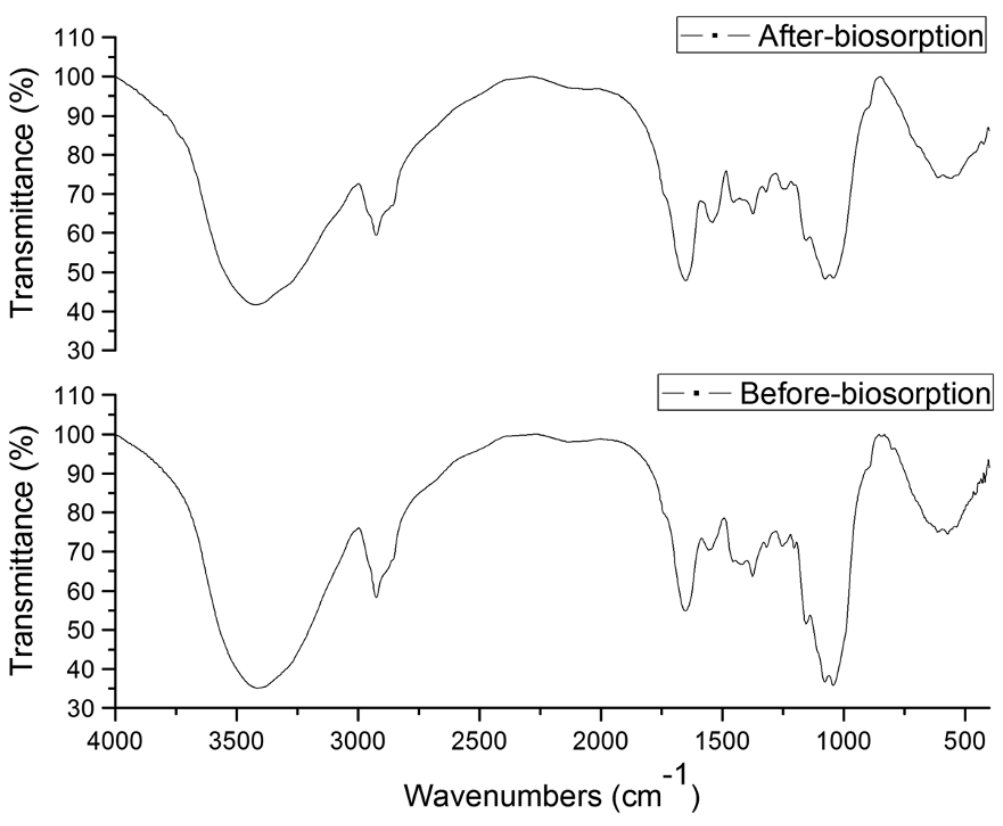

Figure 1 FTIR spectrum of biosorbent (before-biosorption and after-biosorption).

deprotonated at higher $\mathrm{pH}$. Consequently, the initial $\mathrm{pH}$ ranges from 2 to 10 in the experiment.

Figure 3 shows that the percent removal increased gradually from $35.98 \%$ to $95.92 \%$ with increasing of the $\mathrm{pH}$ from 2 to 10, which an increase of nearly $60 \%$ of the percent removal. For MG, a cationic dye, existed in aqueous solution in the form of positively charged ion. In addition, the $\mathrm{pH}_{\mathrm{PZC}}$ of biosorbent was 6.52 , when the $\mathrm{pH}$ from 2 to 6 which was below the $\mathrm{pH}_{\mathrm{PZC}}$, the biosorbent surface was charged positively to limit the adsorption of MG. Furthermore, the biosorbent surface was negatively charged when the $\mathrm{pH}$ was above the $\mathrm{pH}_{\mathrm{PZC}}$ of biosorbent [34]. Nevertheless, when the $\mathrm{pH}$ value was greater than 6 , the removal rate didn't rise as expected.

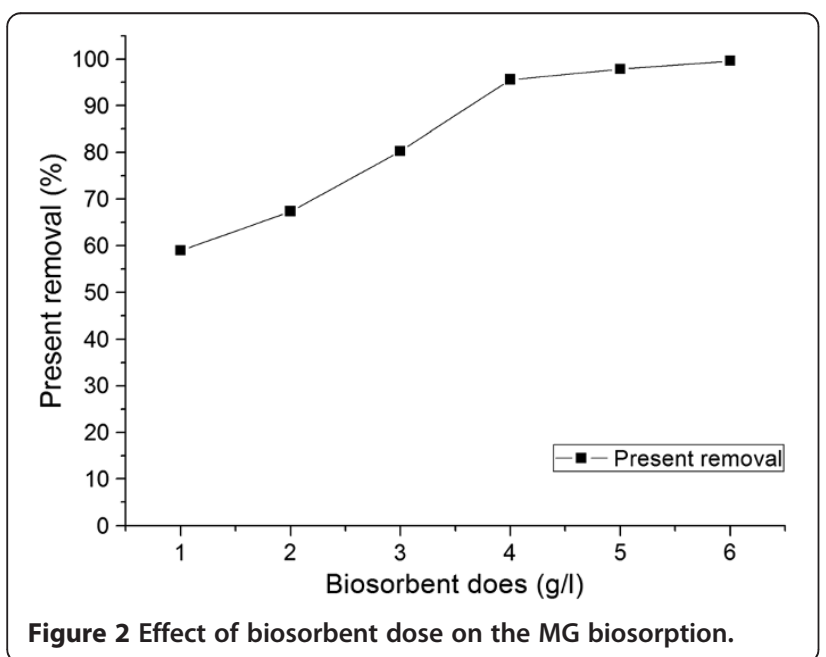

The $\mathrm{pH}$ dependence of dye adsorption was mainly influenced by two factors: firstly, distribution of dye in the solution phase and secondly, overall charge of the adsorbent. A similar result was reported for the biosorption of Neutral Red onto peanut husk [18].

\section{Effect of ionic strength}

There are various impurities, which could be acids, alkalis, salts or metal ions in the wastewaters from textile-manu facturing or dye-producing industries. The presence of cations such as $\mathrm{Na}^{+}, \mathrm{K}^{+}, \mathrm{Cu}^{2+}, \mathrm{Ca}^{2+}$ and $\mathrm{Cr}^{3+}$, which are the most common metal ions existing in dye wastewater that may affect the performance of the biosorption process.

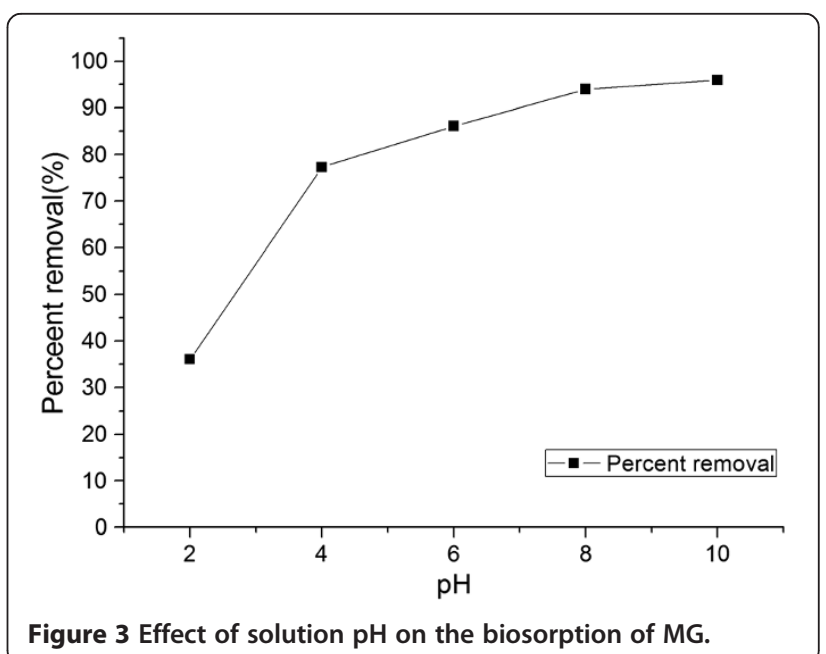


Figure 4 shows the effect of monovalent $\mathrm{Na}^{+}$and divalent $\mathrm{Ca}^{2+}$ on the removal percentage of dye. It was observed that biosorptive capacity for biosorbent decreased with increasing in the concentration of $\mathrm{Na}^{+}$and $\mathrm{Ca}^{2+}$. As concentration of $\mathrm{Na}^{+}$changed from $0.05 \mathrm{M}$ to $0.2 \mathrm{M}$, the percent removal of MG changed from $87.22 \%$ to $49.01 \%$, with a decreased of $38.21 \%$. As concentration of $\mathrm{Ca}^{2+}$ changed from $0.05 \mathrm{M}$ to $0.2 \mathrm{M}$, the percent removal of MG changed from $83.73 \%$ to $43.57 \%$, with a decreased of $40.16 \%$. From 0.05 to $0.2 \mathrm{M}$, all the concentration, divalent ions $\mathrm{Ca}^{2+}$ had a greater inhibition than monovalent ions $\mathrm{Na}^{+}$on the percent removal, which ranged from $3.49 \%$ to $5.44 \%$. With increasing in the concentration, the gap was bigger. It was an adverse effect of ionic strength on MG removal. It may be owed to the possibility of ion exchange mechanisms in the biosorption process. The competition exist between $\mathrm{Na}^{+}, \mathrm{Ca}^{2+}$ and positively charged MG molecules for the same binding sites on the biosorbent surface. $\mathrm{Ca}^{2+}$ had greater positive charge than $\mathrm{Na}^{+}$and had a stronger competitive ability. Similar observations were previously reported in aqueous solution for removal of chromium (VI) by Dunaliella species [35] and dye removal by Poly (propylene imine) Dendrimer [36].

\section{Biosorption isotherms}

As seen of Table 3, the regression coefficient $R^{2}(0.996-$ 0.998) of the linear Freundlich model were higher than the determination coefficient $R^{2}$ (0.906-0.972) of Langmuir model and $R^{2}(0.951-0.956)$ of Temkin model at all the temperatures, which indicated that Freundlich model was well fitted to data than the Langmuir and Temkin isotherm for this study. Moreover, the maximum MG biosorption capacity $\left(q_{m}\right) 111.11 \mathrm{mg} / \mathrm{g}, 125 \mathrm{mg} / \mathrm{g}$, $125 \mathrm{mg} / \mathrm{g}$ which got from Langmuir model at $15^{\circ} \mathrm{C}, 25^{\circ} \mathrm{C}$, $35^{\circ} \mathrm{C}$ were found to be much higher compared with the experimental result $24.437 \mathrm{mg} / \mathrm{g}$. These demonstrated that the process of MG biosorption was in terms of Freundlich

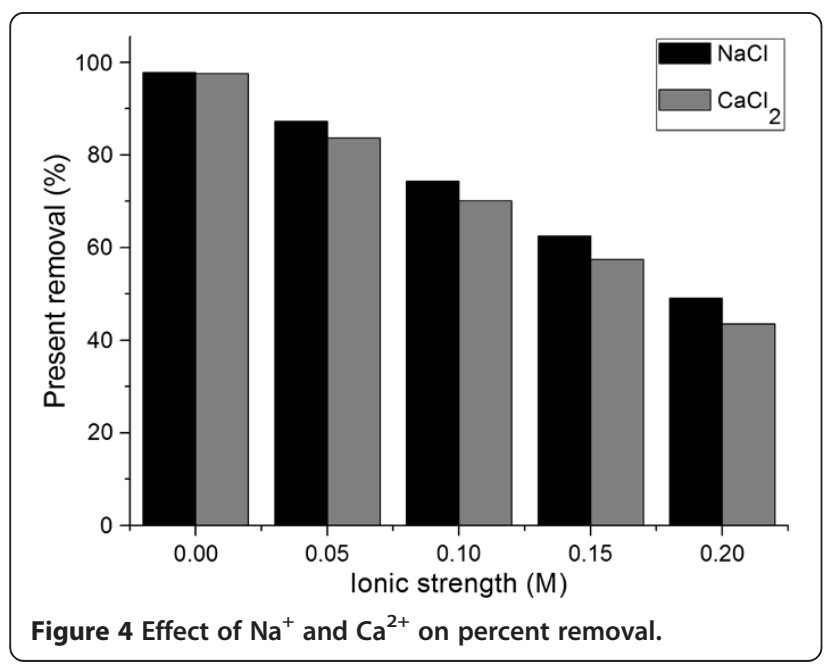

Table 3 Isotherm constants for MG biosorption

\begin{tabular}{lllll}
\hline Isotherm models & Parameters & $\mathbf{1 5}^{\circ} \mathbf{C}$ & $\mathbf{2 5}^{\circ} \mathbf{C}$ & $\mathbf{3 5}^{\circ} \mathbf{C}$ \\
\hline Langmuir & $q_{m}(\mathrm{mg} / \mathrm{g})$ & 111.11 & 125 & 125 \\
& $k_{a}(\mathrm{l} / \mathrm{mg})$ & 0.00222 & 0.00204 & 0.00200 \\
& $R^{2}$ & 0.910 & 0.972 & 0.906 \\
Freundlich & $K_{\mathrm{F}}(\mathrm{L} / \mathrm{g})$ & 0.324 & 0.336 & 0.326 \\
& $n$ & 1.114 & 1.111 & 1.107 \\
& $R^{2}$ & 0.996 & 0.998 & 0.997 \\
temkin & $A$ & 0.0693 & 0.0687 & 0.684 \\
& $B$ & 10.11 & 10.63 & 10.49 \\
& $R^{2}$ & 0.956 & 0.953 & 0.951 \\
\hline
\end{tabular}

model, not Langmuir and Temkin model. For Freundlich model, $K_{\mathrm{F}}(\mathrm{l} / \mathrm{g})$ and $n$ are Freundlich constants which indicated the ease of biosorption and adsorption intensity, respectively. The value of $n$ was bigger than 1 , which indicated the biosorption of MG actively and was a heterogeneous nature biosorption and had rapid adsorption process at studied conditions [37]. $K_{\mathrm{F}}$ and $R^{2}$ at $25^{\circ} \mathrm{C}$ were higher than $15^{\circ} \mathrm{C}, 35^{\circ} \mathrm{C}$. The reason could be that with the temperature increased, the molecular of MG movement became faster, more collision frequency between biosorbent and sorbate. It may also be the higher affinity of binding sites on the biosorbent surfaces.

\section{Adsorption kinetics}

As seen of Figure 5, the MG biosorption occurred in two stages. In the first stage, it was a rapid uptake within $60 \mathrm{~min}$, then in the second stage, it was slow uptake from 60 to $240 \mathrm{~min}$ and reached equilibriumat at $240 \mathrm{~min}$, in this stage, the percent removal of MG did not bring about a significant change.

As seen of Table 4 , the $R^{2}$ values for pseudo-first-order model was range from 0.912 to 0.989 , which was lower than the $R^{2}$ values for pseudo-second-order model which ranged from 0.999 to 1.000 . Moreover, the theoretical $q_{\text {e,cal }}$

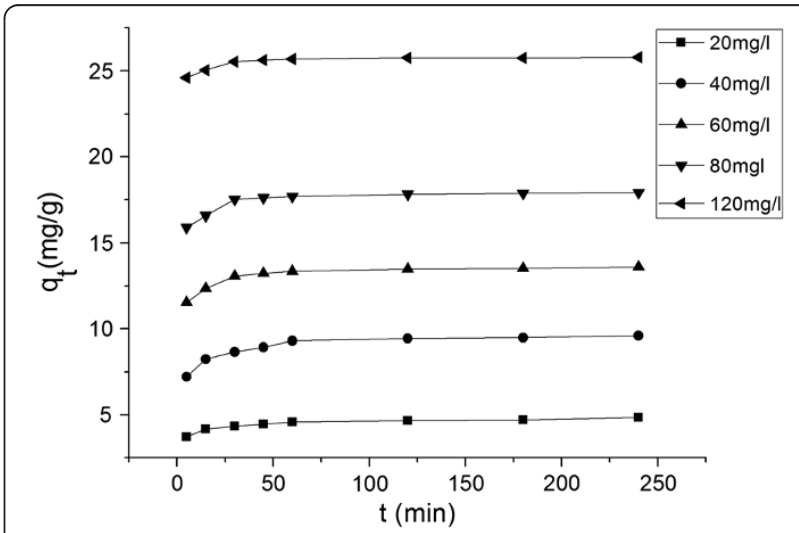

Figure 5 Biosorption at different contact time and different initial MG concentrations. 
Table 4 Kinetic parameters for the removal of MG (temperature $=25^{\circ} \mathrm{C}$, stirring rate $=180 \mathrm{rpm}, \mathrm{pH}=8$ )

\begin{tabular}{|c|c|c|c|c|c|c|c|}
\hline \multirow[t]{2}{*}{$C_{0}(\mathrm{mg} / \mathrm{l})$} & \multirow[t]{2}{*}{$q_{\mathrm{e}, \exp }(\mathrm{mg} / \mathrm{g})$} & \multicolumn{3}{|c|}{ Pseudo-first-order model } & \multicolumn{3}{|c|}{ Pseudo-second-order model } \\
\hline & & $\overline{k_{1}}$ & $k_{\mathrm{e} 1, \mathrm{cal}}(\mathrm{mg} / \mathrm{g})$ & $R^{2}$ & 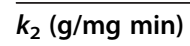 & $q_{\mathrm{e} 2, \mathrm{cal}}(\mathrm{mg} / \mathrm{g})$ & $R^{2}$ \\
\hline 20 & 4.843 & 0.019 & 1.369 & 0.949 & 0.0412 & 4.926 & 0.999 \\
\hline 40 & 9.595 & 0.021 & 1.301 & 0.912 & 0.0809 & 9.709 & 1.000 \\
\hline 60 & 13.604 & 0.472 & 2.300 & 0.989 & 0.0620 & 13.699 & 1.000 \\
\hline 80 & 17.238 & 0.019 & 1.141 & 0.953 & 0.0570 & 17.544 & 1.000 \\
\hline 120 & 24.437 & 0.017 & 0.171 & 0.979 & 0.4000 & 25.000 & 1.000 \\
\hline
\end{tabular}

values for all the studied MG concentration in terms of pseudo-second-order model were more close to the experimental $q_{\text {e,exp }}$ values compared with the pseudo-first-order model.

The initial concentration of MG in the solution remarkably influenced the biosorption. It was noted that initial concentration increased the biosorption of MG (Figure 5). This increase in uptake capacity of the biosorbent with the increase in initial dye concentration is due to higher availability of dye ions for the biosorption [38].

Figure 6 was the linearized plots of the pseudo-secondorder kinetic model for MG biosorption. The data of adsorption kinetics were fitted well to the pseudo-secondorder linear model for different MG concentration.

As showed in Figure 7, the biosorption process was a multi-steps process which included a fast step and a slow step. In the first step, the adsorption active sites on external surface were enough for a fast biosorption. After the first step, the biosorption would get to a steady phase which the intraparticle diffusion was diffusion-controlled.

As seen in Table $5, K_{\mathrm{id}, 1}$ was larger than $K_{\mathrm{id}, 2}$ which demonstrated the biosorption in the first step got a larger rate of transporting the adsorbed MG from exterior to interior of biosorbent particle. The $A_{\mathrm{i}, 2}$ was bigger than $A_{\mathrm{i}, 1}$ the larger intercept for the greater boundary layer effect, which demonstrated that after a fast biosorption process,

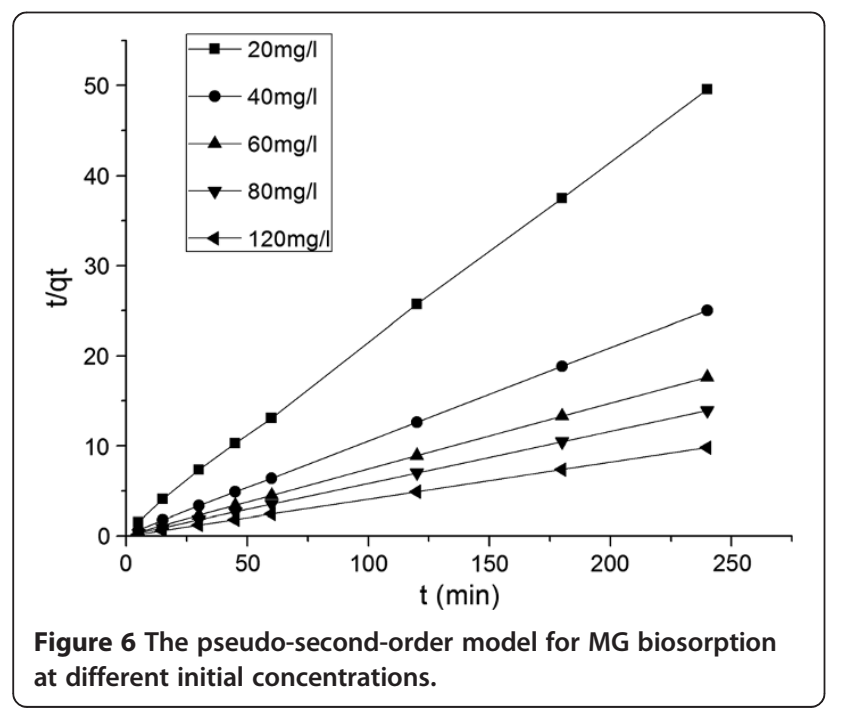

most of MG was on the biosorbent, and most of the adsorption active sites on external surface were occupied and made a thick layer. Therefore, the biosorption rate was controlled by the intraparticle diffusion rate. As seen in Figure 7, there were no plots pass through the origin, thus, it demonstrated that intraparticle diffusion was not the only rate control step. Maybe there were other effect such as complexation or ion exchange mechanisms took effect in biosorption process, and the $R^{2}$ values for intraparticle diffusion model was ranged from 0.8735 and 0.9957 which were lower than the $R^{2}$ values for pseudosecond-order kinetic model.

Many factors influence the adsorption behavior such as structure of dye and adsorbent surface properties. There are many forces which control the adsorption such as van der Waals, hydrogen bonding, steric effect, ion exchange etc. It can be concluded by the results of kinetics that the biosorption process was well in terms of the pseudosecond-order model, which demonstrated that chemisorption was the rate-controlling mechanism through sharing or exchange ions between biosorbent and MG in the biosorption process [39].

\section{Taguchi method}

Range analysis $(R)$ of the results of experiment

As seen of Table 2, the trial 5 with the combination of $\mathrm{pH} 8$, contact time $6 \mathrm{~h}$, biosorbent $0.25 \mathrm{~g}$, and initial

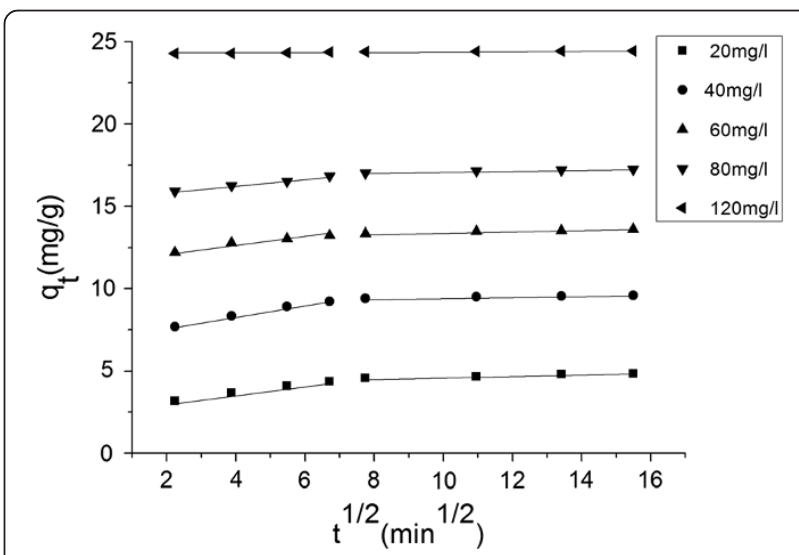

Figure 7 Intraparticle diffusion model for MG biosorption at different initial concentrations. 
Table 5 Intraparticle diffusion kinetic model (temperature $=25^{\circ} \mathrm{C}$, stirring rate $=180 \mathrm{rpm}, \mathrm{pH}=8$ )

\begin{tabular}{|c|c|c|c|c|c|c|}
\hline$C_{0}(\mathrm{mg} / \mathrm{l})$ & $K_{\mathrm{id}, 1}\left(\mathrm{mg} / \mathrm{gmin}^{1 / 2}\right)$ & $A_{\mathrm{i}, 1}$ & $\left(R_{1}\right)^{2}$ & $K_{\mathrm{id}, 2}\left(\mathrm{mg} / \mathrm{g} \min ^{1 / 2}\right)$ & $A_{\mathrm{i}, 2}$ & $\left(R_{2}\right)^{2}$ \\
\hline 20 & 0.2671 & 2.6139 & 0.9957 & 0.0350 & 4.3082 & 0.9485 \\
\hline 40 & 0.3453 & 6.9650 & 0.9878 & 0.0246 & 9.2227 & 0.9467 \\
\hline 60 & 0.2233 & 11.7936 & 0.9263 & 0.0327 & 13.0999 & 0.9697 \\
\hline 80 & 0.2041 & 15.4443 & 0.9902 & 0.0282 & 16.8133 & 0.9444 \\
\hline 120 & 0.0187 & 24.2324 & 0.8735 & 0.0063 & 24.3425 & 0.9753 \\
\hline
\end{tabular}

MG concentration $80 \mathrm{mg} / \mathrm{L}$ had the best percent removal and the trial 8 with the $\mathrm{pH} 9$, contact time $6 \mathrm{~h}$, biosorbent $0.15 \mathrm{~g}$, and initial MG concentration $120 \mathrm{mg} /$ $\mathrm{L}$ had the best biosorption capacity. Range analysis ( $\mathrm{R})$ was used to study the importance of the four factors and get the optimal combination.

The results of $R$ are shown in Table 6. The value of $R$ indicates which factor is more important for the percent removal. $K_{1}, K_{2}$, and $K_{3}$ are the average values of the results of the three different levels of each control factor and can determine the optimal level of the specific control factor in Taguchi method experiment. The $\mathrm{R}$ was used to estimate the effect of the specific control factor. No matter the value of $k_{i}\left(K_{1}, K_{2}\right.$, and $\left.K_{3}\right)$ or the value of $\mathrm{R}$, all of them comply with the principle of "The larger the better". As seen, for percent removal, $\mathrm{A}_{\mathrm{K} 2}, \mathrm{~B}_{\mathrm{K} 2}$, $\mathrm{C}_{\mathrm{K} 3}, \mathrm{D}_{\mathrm{K} 1}$ were larger than others results, therefore, the combination of $\mathrm{A}_{2} \mathrm{~B}_{2} \mathrm{C}_{3} \mathrm{D}_{1}$ which $\mathrm{pH} 8$, contact time $6 \mathrm{~h}$, biosorbent $0.25 \mathrm{~g}$, initial MG concentration $80 \mathrm{mg} / \mathrm{L}$ could reach the best percent removal. Through the experimental test, the percent removal reached $89.58 \%$. From Table 6, it can be seen for $R_{C}>R_{D}>R_{A}>R_{B}$, indicating that the biosorbent does was the most important factor on percent removal. For the reason that sufficient biosorbent may afford available sorption surface and availability of more adsorption sites. For biosorption capacity, $\mathrm{A}_{\mathrm{K} 3}, \mathrm{~B}_{\mathrm{K} 2}$,

Table 6 Range analysis of the experiment

\begin{tabular}{lcccc}
\hline & A & B & C & D \\
\hline \multicolumn{2}{l}{ Percent remove (\%) } & & & \\
$\mathrm{K}_{1}$ & 82.62 & 83.25 & 81.65 & 86.06 \\
$\mathrm{~K}_{2}$ & 84.21 & 84.25 & 83.18 & 83.14 \\
$\mathrm{~K}_{3}$ & 84.11 & 83.45 & 86.01 & 81.75 \\
$\mathrm{R}$ & 1.60 & 1.00 & 4.35 & 4.31 \\
Biosorption & capacity (mg/g) & & & \\
$\mathrm{K}_{1}$ & 20.837 & 21.204 & 27.178 & 17.853 \\
$\mathrm{~K}_{2}$ & 21.989 & 22.416 & 20.747 & 21.623 \\
$\mathrm{~K}_{3}$ & 22.211 & 21.417 & 17.112 & 25.561 \\
$\mathrm{R}$ & 1.374 & 1.212 & 10.066 & 7.708 \\
\hline A & & &
\end{tabular}

A: $\mathrm{pH}$; B: contact time; C: biosorbent dose; D: initial MG concentration. (The levels were showed in Table 2); $\mathrm{K}$ : average value of each level; $\mathrm{R}$ : range of $\mathrm{K}_{1}$, $\mathrm{K}_{2}$ and $\mathrm{K}_{3}$.
$\mathrm{C}_{\mathrm{K} 1}, \mathrm{D}_{\mathrm{K} 3}$ were larger than others results, therefore, the combination of $\mathrm{A}_{3} \mathrm{~B}_{2} \mathrm{C}_{1} \mathrm{D}_{3}$ which $\mathrm{pH}$ 9, contact time $6 \mathrm{~h}$, biosorbent $0.15 \mathrm{~g}$, initial MG concentration $120 \mathrm{mg} / \mathrm{L}$ could have the best biosorption capacity. From Table 6, it can be seen for $R_{C}>R_{D}>R_{B}>R_{A}$, indicating that the biosorbent does was the most important factor on biosorption capacity. For the reason that excessive MG molecule could be fully biosorbed on the surface of the biosorbent. Through the experimental test, the biosorption capacity reached $32.33 \mathrm{mg} / \mathrm{g}$.

\section{Analysis of variance}

Analysis of Variance (ANOVA) is a mathematical method which distinguishes the differences between the test results of different experimental conditions and the differences between the test results of causal factors, and the result of ANOVA could obtain which control factor had significantly effect on percent removal and the biosorption capacity [40]. In order to find which factor significantly effect on remove rate and the biosorption capacity, the conditions differences and random differences influenced by any special factor need to be compared. Square sum of deviations were divided by the Corresponding degree of freedom, the reason of the sum of squares were related to the number of observation and the number of groups, therefore, conditions differences and random differences could not compared directly.

In the ANOVA, the Fischer ratio ( $F$ test) was used to quantify the whole process. The $F$ values of each factor were the ratio of the mean of the squared deviations to the mean of the squared error. The critical values for $F$ test of confidence level at 0.1 and 0.05 were got in experimental design handbooks. Then the $F$ values compared with the critical value at different confidence levels. If the $F$ values was larger than $F_{0.05}$, indicating that the experiment factor was particularly significant effect on the results and marked with “***. If $F$ value was larger than $F_{0.10}$ and smaller than $F_{0.05}$, indicating that the experiment factor was significant effect on the results and marked with "*". At last, if the $F$ value was smaller than $F_{0.10}$, indicating that the experiment factor had no significant effect on the results.

As seen of Table 7, biosorbent does and initial MG concentration had significant influences on the percent 
Table 7 ANOVA for percent removal and biosorption capacity in the $L_{9}\left(3^{4}\right)$ orthogonal array experiment

\begin{tabular}{|c|c|c|c|c|c|c|}
\hline Variance sources & $S S S D^{a}$ & DOF $^{b}$ & Mean square & $F$ ratio & $F$ critical value & Significance \\
\hline \multicolumn{7}{|l|}{ Percent removal } \\
\hline A & $4.82 \times 10^{-4}$ & 2 & $2.41 \times 10^{-4}$ & 2.849 & $F_{0.05}(2,2)=19.0$ & \\
\hline B & $1.68 \times 10^{-4}$ & 2 & $8.40 \times 10^{-5}$ & 0.996 & $F_{0.10}(2,2)=9.0$ & \\
\hline C & $29.00 \times 10^{-4}$ & 2 & $14.50 \times 10^{-4}$ & 17.160 & & * \\
\hline D & $29.01 \times 10^{-4}$ & 2 & $14.51 \times 10^{-4}$ & 17.163 & & * \\
\hline Error & $1.69 \times 10^{-4}$ & 2 & & & & \\
\hline Total & $66.20 \times 10^{-4}$ & 10 & & & & \\
\hline \multicolumn{7}{|l|}{ Biosorption capacity } \\
\hline A & 3.267 & 2 & 1.634 & 1 & $F_{0.05}(2,2)=19.0$ & \\
\hline B & 2.511 & 2 & 1.256 & 0.769 & $F_{0.10}(2,2)=9.0$ & \\
\hline C & 155.903 & 2 & 77.951 & 47.716 & & $* *$ \\
\hline D & 89.127 & 2 & 44.564 & 27.279 & & $* *$ \\
\hline Error & 3.267 & 2 & & & & \\
\hline Total & 254.076 & 10 & & & & \\
\hline
\end{tabular}

$\mathrm{SSD}^{\mathrm{a}}$ : Sum of Squares of Deviations; DOF ${ }^{\mathrm{b}}$ : Degree of Freedom.

A: $\mathrm{pH}$; B: contact time; C: biosorbent dose; D: initial MG concentration. The levels were showed in Table 1 . Significance levels at $95 \%$ and $90 \%$ confidence interval, $\mathrm{F}_{0.05}(2,2)=19, \mathrm{~F}_{0.10}(2,2)=9$.

'*' indicate the experiment factor was significant effect on the results; ${ }^{* * \prime}$ indicate the experiment factor was particularly significant effect on the results.

removal. Biosorbent does and initial MG concentration had particularly significant influences on biosorption capacity. The values of $F$ were 47.716 and 27.279 for biosorbent does and initial MG concentration, respectively. From the results of ANOVA, it indicated that the biosorption process was not influenced by the time and the environment $\mathrm{pH}$ under the condition of this study. In practice, it will show stability in the biosorption process.

\section{Conclusions}

This study confirmed that Pleurotus ostreatus has the potential to be an economical biosorbent for the removal of MG, a hazardous cationic dye, from wastewater. The biosorption effect in alkaline condition was better than in acidic condition, but $\mathrm{pH}$ affected the structural stability of MG and its color intensity when $\mathrm{pH}$ was more than 10 . MG was almost adsorbed by biosorbent when the initial MG concentration was low in solution. Biosorbent dose, time and $\mathrm{pH}$ were important for biosorption in the single factor analysis. Monovalent $\mathrm{Na}^{+}$and divalent $\mathrm{Ca}^{2+}$ were found to have an adverse effect on MG removal. Equilibrium time was nearly $240 \mathrm{~min}$. The biosorption equilibrium data were followed the Freundlich isotherm model. The biosorption process was found to follow the pseudosecond-order kinetic model, indicating that chemical biosorption was the rate-controlling mechanism through sharing or exchange ions between biosorbent and MG in the biosorption process.
For the Taguchi method experiment, the optimum condition for percent removal and biosorption capacity were found out. The combination of $\mathrm{A}_{2} \mathrm{~B}_{2} \mathrm{C}_{3} \mathrm{D}_{1}$ which $\mathrm{pH} 8$, contact time $6 \mathrm{~h}$, biosorbent $0.25 \mathrm{~g}$, initial MG concentration $80 \mathrm{mg} / \mathrm{L}$ could reach the highest percent removal 89.58\%. And the combination of $\mathrm{A}_{3} \mathrm{~B}_{2} \mathrm{C}_{1} \mathrm{D}_{3}$ which $\mathrm{pH} 9$, contact time $6 \mathrm{~h}$, biosorbent $0.15 \mathrm{~g}$, initial MG concentration $120 \mathrm{mg} / \mathrm{L}$ could reach the largest biosorption capacity $32.33 \mathrm{mg} / \mathrm{g}$. The results of FTIR spectroscopy showed the existence of the functional groups such as, carboxyl, hydroxyl, amino and phosphonate groups on the biosorbent surface.

\section{Abbreviations}

MG: Malachite green; FTIR: Fourier transform infrared; ANOVA: Analysis of variance; SPSS: Statistical Package for the Social Sciences; R: Range analysis; F: Fischer ratio.

\section{Competing interests}

The authors declare that they have no competing interests.

\section{Authors' contributions}

All authors read and approved the final manuscript.

\section{Acknowledgements}

This study was financially supported by the Science and Technology Supportive Project of Sichuan Province, China (No. 2013SZ0062),

Science and Technology Supportive Project of Chengdu

(No. 12DXYB087JH-005) and NSFC (No. J1103518). The authors wish to thank Professor Guanglei Cheng and Dong Yu from Sichuan University for their technical assistance.

Received: 8 April 2013 Accepted: 5 March 2014 Published: 12 March 2014 
References

1. Tian X, Li C, Yang H, Ye Z, Xu H: Spent mushroom: a new low-cost adsorbent for removal of congo red from aqueous solutions. Desalin Water Treat 2011, 27:319-326.

2. El Qada EN, Allen SJ, Walker GM: Adsorption of basic dyes from aqueous solution onto activated carbons. Chem Eng J 2008, 135:174-184.

3. Crini G: Non-conventional low-cost adsorbents for dye removal: a review. Bioresourc Technol 2006, 97:1061-1085.

4. Allen S, Mckay G, Porter J: Adsorption isotherm models for basic dye adsorption by peat in single and binary component systems. J Colloid Interf Sci 2004, 280:322-333.

5. Mall ID, Srivastava VC, Agarwal NK, Mishra IM: Adsorptive removal of malachite green dye from aqueous solution by bagasse fly ash and activated carbon-kinetic study and equilibrium isotherm analyses. Colloid Surf A 2005, 264:17-28.

6. Pierrard M-A, Kestemont P, Delaive E, Dieu M, Raes M, Silvestre F: Malachite green toxicity assessed on Asian catfish primary cultures of peripheral blood mononuclear cells by a proteomic analysis. Aquat Toxicol 2012, 114:142-152.

7. Bose B, Motiwale L, Rao K: DNA damage and G2/M arrest in Syrian hamster embryo cells during Malachite green exposure are associated with elevated phosphorylation of ERK1 and JNK1. Cancer Lett 2005, 230:260-270.

8. $\quad$ Ding F, Li X-N, Diao J-X, Sun Y, Zhang L, Ma L, Yang X-L, Sun Y: Potential toxicity and affinity of triphenylmethane dye malachite green to lysozyme. Ecotox Environ Saf 2012, 78:41-49.

9. Srivastava S, Sinha R, Roy D: Toxicological effects of malachite green. Aquat Toxicol 2004, 66:319-329.

10. Stammati A, Nebbia C, Angelis ID, Albo AG, Carletti M, Rebecchi C, Zampaglioni F, Dacasto M: Effects of malachite green (MG) and its major metabolite, leucomalachite green (LMG), in two human cell lines. Toxicol In Vitro 2005, 19:853-858.

11. Singh S, Das M, Khanna SK: Biodegradation of malachite green and rhodamine B by cecal microflora of rats. Biochem Biophysic Res Commun 1994, 200:1544-1550.

12. Chakravarty S, Mohanty A, Sudha TN, Upadhyay A, Konar J, Sircar J, Madhukar A, Gupta K: Removal of $\mathrm{Pb}$ (II) ions from aqueous solution by adsorption using bael leaves (Aegle marmelos). J Hazard Mater 2010, 173:502-509.

13. Ai $L$, Zhou $Y$, Jiang J: Removal of methylene blue from aqueous solution by montmorillonite/ $\mathrm{CoFe}_{2} \mathrm{O}_{4}$ composite with magnetic separation performance. Desalination 2011, 266:72-77.

14. Garg VK, Kumar R, Gupta R: Removal of malachite green dye from aqueous solution by adsorption using agro-industry waste: a case study of Prosopis cineraria. Dyes Pigments 2004, 62:1-10.

15. Gupta VK, Mittal A, Kurup L, Mittal J: Adsorption of a hazardous dye, erythrosine, over hen feathers. J Colloid Interf Sci 2006, 304:52-57.

16. Panda GC, Das SK, Guha AK: Jute stick powder as a potential biomass for the removal of congo red and rhodamine $B$ from their aqueous solution. J Hazard Mater 2009, 164:374-379.

17. Hameed B: Spent tea leaves: a new non-conventional and low-cost adsorbent for removal of basic dye from aqueous solutions. J Hazard Mater 2009, 161:753-759.

18. Han R, Han P, Cai Z, Zhao Z, Tang M: Kinetics and isotherms of neutral red adsorption on peanut husk. J Environ Sci 2008, 20:1035-1041.

19. Oguz E: Adsorption characteristics and the kinetics of the $\mathrm{Cr}(\mathrm{VI})$ on the Thuja oriantalis. Colloid Surf A 2005, 252:121-128.

20. Cao Y-r, Liu Z, Cheng G-l, Jing X-b, Xu H: Exploring single and multi-metal biosorption by immobilized spent Tricholoma lobayense using multi-step response surface methodology. Chem Eng J 2010, 164:183-195.

21. Maurya NS, Mittal AK, Cornel P, Rother E: Biosorption of dyes using dead macro fungi: effect of dye structure, ionic strength and $\mathrm{pH}$. Bioresour Technol 2006, 97:512-521.

22. Akar ST, Gorgulu A, Kaynak Z, Anilan B, Akar T: Biosorption of reactive blue 49 dye under batch and continuous mode using a mixed biosorbent of macro-fungus Agaricus bisporus and Thuja orientalis cones. Chem Eng J 2009, 148:26-34

23. Olivieri G, Marzocchella A, Salatino P, Giardina P, Cennamo G, Sannia G: Olive mill wastewater remediation by means of Pleurotus ostreatus. Biochem Eng J 2006, 31:180-187.
24. Javaid A, Bajwa R, Shafique U, Anwar J: Removal of heavy metals by adsorption on < Pleurotus ostreatus. Biomass Bioenergy 2011, 35:1675-1682.

25. Arslan CS, Dursun AY: Biosorption of phenol on dried activated sludge: effect of temperature. Sep Sci Tech 2008, 43:3251-3268.

26. Abu Al-Rub FA: Biosorption of zinc on palm tree leaves: equilibrium, kinetics, and thermodynamics studies. Sep Sci Tech 2006, 41:3499-3515.

27. Namasivayam C, Kavitha D: Removal of congo red from water by adsorption onto activated carbon prepared from coir pith, an agricultural solid waste. Dyes Pigments 2002, 54:47-58.

28. Ahmad R, Kumar R: Adsorption of amaranth dye onto alumina reinforced polystyrene. Clean Soil Air Water 2011, 39:74-82.

29. Mane VS, Mall ID, Srivastava VC: Use of bagasse fly ash as an adsorbent for the removal of brilliant green dye from aqueous solution. Dyes Pigments 2007, 73:269-278.

30. Bayramoğlu G, Çelik G, Arica MY: Biosorption of reactive blue 4 dye by native and treated fungus Phanerocheate chrysosporium: Batch and continuous flow system studies. J Hazard Mater 2006, 137:1689-1697.

31. Chen G-Q, Zeng G-M, Tu X, Niu C-G, Huang G-H, Jiang W: Application of a by-product of Lentinus edodes to the bioremediation of chromate contaminated water. J Hazard Mater 2006, 135:249-255.

32. Han MH, Yun Y-S: Mechanistic understanding and performance enhancement of biosorption of reactive dyestuffs by the waste biomass generated from amino acid fermentation process. Biochem Eng J 2007, 36:2-7.

33. Zhang J, Li Y, Zhang C, Jing Y: Adsorption of malachite green from aqueous solution onto carbon prepared from Arundo donax root. $J$ Hazard Mater 2008, 150:774-782

34. Jing X, Cao Y, Zhang X, Wang D, Wu X, Xu H: Biosorption of $\mathrm{Cr}(\mathrm{VI})$ from simulated wastewater using a cationic surfactant modified spent mushroom. Desalination 2011, 269:120-127.

35. Dönmez G, Aksu Z: Removal of chromium (VI) from saline wastewaters by Dunaliella species. Process Biochem 2002, 38:751-762.

36. Hayati B, Mahmoodi NM, Arami M, Mazaheri F: Dye removal from colored textile wastewater by poly (propylene imine) dendrimer: operational parameters and isotherm studies. Clean Soil Air Water 2011, 39:673-679.

37. Arıca MY, Bayramoğlu G: Biosorption of reactive red-120 dye from aqueous solution by native and modified fungus biomass preparations of Lentinus sajor-caju. J Hazard Mater 2007, 149:499-507.

38. Vimala R, Das N: Biosorption of cadmium (II) and lead (II) from aqueous solutions using mushrooms: a comparative study. J Hazard Mater 2009, 168:376-382.

39. Liu $Y$, Wang W, Wang A: Removal of congo red from aqueous solution by sorption on organified rectorite. Clean Soil Air Water 2010, 38:670-677.

40. Raghunath N, Pandey PM: Improving accuracy through shrinkage modelling by using Taguchi method in selective laser sintering. Inte J Mach Tool Manu 2007, 47:985-995.

\section{doi:10.1186/2052-336X-12-63}

Cite this article as: Chen et al:: Biosorption of malachite green from aqueous solutions by Pleurotus ostreatus using Taguchi method. Journal of Environmental Health Science \& Engineering 2014 12:63.

\section{Submit your next manuscript to BioMed Central and take full advantage of:}

- Convenient online submission

- Thorough peer review

- No space constraints or color figure charges

- Immediate publication on acceptance

- Inclusion in PubMed, CAS, Scopus and Google Scholar

- Research which is freely available for redistribution 